\title{
RECURRENCE RATE OF HELICOBACTER PYLORI IN PATIENTS WITH PEPTIC ULCER FIVE YEARS OR MORE AFTER SUCCESSFUL ERADICATION
}

\author{
Yuri Costa Farago FERNANDES ${ }^{1}$, Gabriel da Rocha BONATTO ${ }^{2}$ and \\ Mauro Willeman BONATTO1,3
}

Received 30/1/2016 Accepted 29/3/2016

\begin{abstract}
Background - Infection with Helicobacter pylori is highly prevalent worldwide, especially in developing countries. Its presence in the gastroduodenal mucosa is related with development of peptic ulcer and other illnesses. The eradication of H. pylori improves mucosal histology in patients with peptic ulcers. Objective - This study was aimed to verify if $H$. pylori recurrence occurs five years or more after confirmed eradication in patients with peptic ulcer. Moreover, we sought to determine the recurrence rate. Methods - Retrospective and longitudinal, this study was based on a sample of 201 patients from western Paraná, Brazil. The patients were diagnosed with peptic ulcer disease, in the period of 1990-2000, and followed for five years or more after successful H. pylori eradication. Patients with early recurrence - prior to five years after eradication - were excluded from the sample. Results - During an average follow-up of 8 years, 180 patients $(89.55 \%)$ remained negative, and $21(10.45 \%)$ became positive for H. pylori infection. New ulcers appeared in two-thirds of the patients with H. pylori recurrence. Conclusion - The recurrence of H. pylori in patients with peptic ulcer can occur in the long-term - even if the infection had been successfully eradicated and the patients had remained free of recurrence in the first years of follow-up.
\end{abstract}

HEADINGS - Helicobacter pylori. Peptic ulcer. Recurrence.

\section{INTRODUCTION}

The Gram-negative spirochaete and pathogen Helicobacter pylori (H. pylori) may have originated in Africa 58,000 years ago ${ }^{(15)}$. H. pylori was first reported in 1875, when Bottcher and Letulle observed it on margins of peptic ulcers. However, its role in gastrointestinal diseases was not demonstrated until 1983, a discovery which earned Warren and Marshall a Nobel Prize in Physiology or Medicine in 2005 and rekindled interest in the study of this microorganism. Since then, the association of $H$. pylori and digestive tract diseases has been object of much research ${ }^{(13)}$.

\section{LITERATURE}

The $H$. pylori infection is highly prevalent throughout the world, especially in developing countries. Despite the decreasing prevalence over the past decades, the pathogen is becoming increasingly resistant to antibiotics used in therapy $y^{(4,18,22,25)}$. In Brazil, the prevalence ranges from $50 \%$ to $80 \%$ in different populations ${ }^{(8,17,20)}$.
The presence of $H$. pylori in gastroduodenal mucosa and its involvement in the development of chronic gastritis, carcinoma, lymphoma and other illnesses are well documented. Moreover, a strong link exist between peptic ulcer disease and $H$. pylori infection ${ }^{(12)}$.

However, the role of $H$. pylori in the human organism is not fully understood ${ }^{(10)}$. Recently, the presence of $H$. pylori in gall bladder mucosa was found to be associated with development of chronic calculous cholecystitis. In fact, $H$. pylori may be the cause of the chronic inflammation observed in this condition $^{(7)}$. The preliminary results of a Chinese study showed that the infection with $H$. pylori (especially of the CagA serotype) is a significant risk factor for development of pancreatic cancer ${ }^{(2)}$. On the other hand, some authors have questioned whether the H. pylori colonization could offer benefits to its human host ${ }^{(1)}$.

Infection with $H$. pylori can be diagnosed with endoscopic techniques (staining, culture or urease test) or non-endoscopic techniques (C13/C14-urea breath test, serology, molecular biology and antigen detection 
in stools). Both types can reliably detect the infection and evaluate treatment success ${ }^{(11)}$.

First-line therapy schemes, which currently combine two antibiotics and a proton pump inhibitor, achieve reasonably high cure rates. Yet, sometimes, the infection is refractory, making necessary to consider alternative schemes. In addition, even when the pathogen has been successfully eradicated, recurrence is possible ${ }^{(16,24)}$.

The purpose of this retrospective study was to determine if recurrence of $H$. pylori infection occurs in the long-term - 5 years or more after confirmed eradication - in patients with peptic ulcer. Moreover, if recurrence occurred, we sought to determine at which rate.

\section{METHODS}

In this retrospective and longitudinal study, the population consisted of patients with peptic ulcer disease treated in the period from 1990 to 2000 . The data were collected from an electronic database at the Gastroclínica Cascavel, a referral center in Western Paraná, Brazil. The patients were selected based on codes for peptic ulcer disease presented in the 9th and 10th revision of the International Statistical Classification of Diseases and Related Health Problems (ICD).

To be included in the sample, patients should: I) have a history of duodenal or gastric ulcer (or ulcer scar) on esophagogastroduodenoscopy (EGD); II) have a history of infection with $H$. pylori prior to treatment, confirmed by histological analysis according to the Sydney System and urease test; III) have tested negative for $H$. pylori on the same tests approximately three months after treatment, indicating successful eradication of the pathogen; and IV) have been followed for at least 5 years after eradication. To test for $H$. pylori infection - at baseline, at the control evaluation after treatment, and during the follow-up - histological analyses graded according to the Sydney System and urease tests were performed on biopsy fragments (two from the anterior and posterior antrum wall and two from the distal and proximal corpus).

Patients without confirmed eradication of $H$. pylori or patients that became positive for $H$. pylori in less than 5 years after the eradication were excluded from the study.

The sample was characterized regarding sex, age and type of mucosal lesion initially presented at EGD. The schemes used to treat the infection were either a triple regimen for 14 days (amoxicillin 1g/day + clarithromycin 500mg/day + proton pump inhibitor) or a bismuth regimen for 14 days (bismuth compound + metronidazole $500 \mathrm{mg} /$ day + tetracycline $500 \mathrm{mg} /$ day, sometimes with addition of a proton pump inhibitor). The recurrence of $H$. pylori and the presence of active ulcers during the follow-up were verified. Use of non-steroidal anti-inflammatory drugs (NSAIDs) was investigated in patients with new ulcers.

The statistical analysis was performed with the software QuickCalcs (GraphPad Software, Inc. 2015. La Jolla, California, USA). Categorical variables were expressed as relative and absolute values, while numerical variables were expressed as mean and standard deviation (SD). Fisher's exact test was used to detect statistically significant differences between categorical variables. A two-tailed $P$-value of less than 0.05 was considered statistically significant.

The study protocol was previously approved by the $\mathrm{Hu}-$ man Research Ethics Committee of Faculdade Assis Gurgacz and filed under case number 868.091.

\section{RESULTS}

The sample consisted of 201 patients that satisfied the study criteria. The average age was $47.1(\mathrm{SD} \pm 7)$ years and most individuals were male $(\mathrm{n}=113 ; 56.2 \%)$. All patients tested positive at baseline for $H$. pylori infection on histological examination and urease test. The majority had active ulcers documented at baseline EGD $(n=146 ; 72.6 \%)$. On the other hand, ulcer scar was found in almost one-third $(n=55$; $27.4 \%$ ) of the patients. A large proportion of the individuals had the peptic ulcer disease located at duodenum $(n=149$; $74.1 \%$ ). (Table 1).

TABLE 1. Characteristics of 201 patients with peptic ulcer disease treated for $H$. pylori infection, in the period of 1990-2000, and followed for 5 years or more after successful $H$. pylori eradication

\begin{tabular}{ll}
\hline Characteristic & \\
\hline Gender & $\mathrm{n}=113(56.2 \%)$ \\
Male & $\mathrm{n}=88(43.8 \%)$ \\
Female &
\end{tabular}

Age in years (mean)

$\begin{array}{lc}\text { All patients } & 47.1(\mathrm{SD} \pm 7) \\ \text { Males } & 51\left(\mathrm{SD}_{ \pm} 7.6\right) \\ \text { Females } & 42.2(\mathrm{SD} \pm 6.2)\end{array}$

Lesion documented on EGD
Duodenal ulcer

Duodenal ulcer scar

$\mathrm{n}=45(22.4 \%)$

Gastric ulcer

$\mathrm{n}=42(20.9 \%)$

Gastric ulcer scar

$\mathrm{n}=10(5 \%)$ $\mathrm{n}=104(51.7 \%)$

EGD: esophagogastroduodenoscopy; SD: standard deviation.

The treatment employed to eradicate the $H$. pylori were either a triple regimen or a bismuth regimen. All patients tested negative for $H$. pylori in histological analyses and urease test after therapy. The average interval between treatment and control evaluation was 81.3 days ( $\mathrm{SD} \pm 12.5$ days).

The patients were followed for 5 or more years after eradication. Patients with early recurrence - prior to 5 years since the eradication - are not part of this study. The mean time of follow-up was 8.1 years ( $\mathrm{SD} \pm 2.4$ years) with a median of 7.6 years. 
On the follow-up, $180(89.6 \%)$ of the 201 patients continually tested negative for $H$. pylori on histopathological examination and urease test, while $21(10.4 \%)$ patients became positive for $H$. pylori infection.

In two-thirds of the patients with infection recurrence, active ulcers were found during follow-up ( $n=14 ; 66.7 \%$ ). These patients had the new ulcers identified at EGD at same time the reinfection was documented, and were not taking NSAIDs. No patients in the group without $H$. pylori recurrence had new ulcers during follow-up. The relation between $H$. pylori recurrence and active ulcers on follow-up was statistically significant $(P<0.05)$. On the EGD, the 21 patients with $H$. pylori recurrence presented: duodenal ulcer $(\mathrm{n}=11$; $52.4 \%)$; duodenal ulcer scar $(n=6 ; 28.6 \%)$; gastric ulcer $(n=2$; $9.5 \%)$; gastric ulcer scar $(\mathrm{n}=1 ; 4.8 \%)$; or both duodenal and gastric ulcer $(n=1 ; 4.8 \%)$. (Table 2$)$.

TABLE 2. Relation between $H$. pylori recurrence and active peptic ulcer during follow-up, of 201 patients with peptic ulcer disease treated for $H$. pylori infection, in the period of 1990-2000, and followed for 5 years or more after successful $H$. pylori eradication

\begin{tabular}{lcc}
\hline $\begin{array}{l}\text { H. pylori recurrence } \\
\text { on follow-up }\end{array}$ & \multicolumn{2}{c}{ Active peptic ulcer on follow-up } \\
& No & Yes \\
\hline No & $\mathrm{n}=180(89.6 \%)$ & $\mathrm{n}=0$ \\
Yes & $\mathrm{n}=7(3.5 \%)$ & $\mathrm{n}=14(7 \%)$ \\
\hline
\end{tabular}

Statistically significant result $(P<0.05)$.

\section{DISCUSSION}

Treatment for peptic ulcer was for many decades surgical. In fact, gastrectomy (Billroth I and II) was introduced already in 1888. Later techniques, such as partial gastrectomy, antrectomy and vagotomy (posteriorly, selective and highly selective vagotomy), improved outcomes, but the surgical approach continued to be associated with high levels of morbidity and mortality ${ }^{(23)}$.

Throughout the twentieth century, the pathophysiology and treatment of peptic ulcer were widely discussed, leading to the emergence of several theories. In 1972, James Black first identified histamine receptors in parietal cells. The ensuing development of antacid drugs capable of blocking these receptors opened up new horizons in the treatment of peptic ulcer. Black was consequently awarded the Nobel Prize in Physiology or Medicine in $1988^{(23)}$. Nevertheless, the rediscovery of $H$. pylori and its role in gastrointestinal disease caused a major impact on the management of this condition ${ }^{(13)}$. Previously associated with high rates of mortality or severe complications (such as perforation, hemorrhage and stenosis), peptic ulcer is now treated effectively with antibiotics and oral antacids, while surgery has become restricted to treatment of complications. Drug therapy initially consisted of bismuth regimens that induced intolerance and serious adverse effects ${ }^{(19)}$. In contrast, currently available commercial kits are associated with few undesired effects. However, new challenges in the management of this condition have appeared ${ }^{(25)}$.
This study allowed verifying if recurrence of $H$. pylori infection occurs in the long-term -5 years or more after confirmed eradication - in patients with peptic ulcer, treated in the period from 1990 to 2000 .

The sample was composed by individuals with an average age of 47 years, with a slightly predominance of males. Most patients had active ulcers documented at baseline EGD. This finding is probably related with an increase in the search for medical attention during symptomatic periods of the disease.

The patients received either a triple regimen (amoxicillin, clarithromycin and a proton pump inhibitor) or a bismuth regimen (bismuth compound, metronidazole, and tetracycline, sometimes with a proton pump inhibitor) for $\mathrm{H}$. pylori eradication. However, since only patients with confirmed eradication - through histological examination and urease test - joined the study, was impossible to compare efficacy between treatments in eradicating the Helicobacter. The control evaluation to document eradication was performed an average of 81 days after treatment.

This study had focused on long-term recurrence. The patients were followed for an average of 8 years, showing that, recurrence can occur even if the patient had eradication confirmed and had remained free of $H$. pylori during the first years of follow-up after treatment. Due to the study design (regarding confirmed eradication and exclusion of patients with early recurrence), is most probable that patients whom became positive again suffered true reinfection. However, only molecular methods can accurately differ between reinfection and recrudescence ${ }^{(14)}$.

The recurrence rate of $H$. pylori found $(10.5 \%)$ is close to figures reported in other Brazilian studies ${ }^{(3,5,6,21)}$. In these researches, recurrence rate ranged between $5 \%$ and $20 \%$. However, it should be noted that this studies are heterogeneous regarding design. Generally, research on recurrence rate of $H$. pylori were aimed on the first 5 years post-treatment.

The H. pylori recurrence is closely associated with an increase in the incidence of new ulcers ${ }^{(9)}$. This is supported by our finding of new ulcers in two-thirds of the patients with $H$. pylori reinfection. Reinforcing this idea, no patients had active ulcers during follow-up on the group without reinfection. The association between reinfection and new ulcers was statistically significant $(P<0.05)$.

This study suffered with limitations, most due to its retrospective design. The patients were tested at heterogeneous intervals during follow-up, therefore, was not possible to describe the interval between eradication and reinfection/ development of new ulcers. For example, if a patient had a 3 years interval between tests, with $H$. pylori recurrence documented on the later evaluation, was not possible to determine when, on this 3 years interval, the reinfection really occurred. Moreover, the incidence of active ulcers was high among patients with reinfection - such patients may have been inclined to seek medical attention due to symptoms, potentially leading to an overestimation of the recurrence rate.

Despite its limitations, few studies were aimed to determine the recurrence rate among Brazilian patients 
5 years or more after eradication. Our findings suggest that, despite the treatment had effectively reduced the incidence of gastrointestinal ulcer in the long-term - only $7 \%$ of the sample had new ulcers - the risk of recurrence cannot be discarded. Even long years after H. pylori eradication, reinfection or recrudescence should be suspected, especially if the patients became symptomatic again. The best way to follow patients with peptic ulcer after successful treatment for $H$. pylori is discussable. Ideally, the cost-effectiveness of subsequent medical interventions, the local recurrence rate and the individual risk of complications should be considered. Other long-term studies on recurrence of $H$. pylori, especially with prospective design, can help establish follow-up criteria for patients with peptic ulcer and determine to what extent therapy is protective over long periods.

\section{CONCLUSION}

The recurrence of $H$. pylori in patients with peptic ulcer can occur in the long-term - even if the infection had been successfully eradicated and the patients had remained negative during the initial years of follow-up. The recurrence rate of $H$. pylori was $10.4 \%$. Two-thirds of the patients with $H$. pylori recurrence also experienced new ulcers. Additionally, patients that had remained negative for $H$. pylori did not presented active ulcers during follow-up.

\section{Authors' contributions}

Fernandes YCF: study design, data collection, statistical analysis, manuscript writing. Bonatto GR: study design, data collection. Bonatto MW: study design, critical review and corrections of manuscript.

Fernandes YCF, Bonatto GR, Bonatto MW. Taxa de reinfecção por Helicobacter pylori em pacientes com úlcera péptica cinco anos após erradicação. Arq Gastroenterol. 2016,53(3):152-5.

RESUMO - Contexto - A infecção por Helicobacter pylori é altamente prevalente no mundo, especialmente nos países em desenvolvimento, e sua presença na mucosa gastroduodenal está associada com o desenvolvimento de úlcera péptica e outras patologias. A erradicação do $H$. pylori melhora a histologia da mucosa em pacientes com úlcera péptica. Objetivo - Determinar se a recorrência da infecção por $H$. pylori ocorre cinco anos ou mais após a erradicação confirmada em pacientes com úlcera péptica. Além disso, buscou-se determinar a taxa de recorrência. Método - Retrospectivo e longitudinal, o estudo foi baseado em uma amostra de 201 pacientes oriundos da região Oeste do Paraná, Brasil. Os pacientes foram diagnosticados com úlcera gástrica e/ou duodenal, no período de 1990-2000, e foram seguidos por pelo menos cinco anos após a erradicação com sucesso do H. pylori. Pacientes com recorrência precoce - nos primeiros cinco anos após a erradicação - foram excluídos da amostra. Resultados - Após um tempo médio de seguimento de oito anos, 180 pacientes $(89,55 \%)$ permaneceram negativos e $21(10,45 \%)$ tornaram-se positivos para a presença de $H$. pylori. Novas úlceras apareceram em dois terços dos pacientes com recorrência da bactéria. Conclusão - A recorrência da infecção por H. pylori ocorre em longo prazo - mesmo se a infecção tiver sido erradicada com sucesso e os pacientes permanecido livres de recorrência nos primeiros cinco anos de seguimento.

DESCRITORES - Helicobacter pylori. Úlcera Péptica. Recidiva.

\section{REFERENCES}

1. Abadi ATB. Helicobacter pylori: a beneficial gastric pathogen?. Gastroenterology. 2014;1:26.

2. Ai F, Hua X, Liu Y, Lin J, Feng Z. Preliminary study of pancreatic cancer associated with Helicobacter pylori infection. Cell Biochem Biophys. 2014;71:397-400.

3. Coelho LGV, Passos MCF, Chausson Y, Costa EL, Maia AF, Brandao MJCC, et al. Duodenal ulcer and eradication of Helicobacter pylori in a developing country an 18-month follow-up study. Scand J Gastroenterol. 1992;27:362-6.

4. De-Francesco V, Giorgio F, Hassan C, Manes G, Vannella L, Panella C, et al. Worldwide $H$. pylori antibiotic resistance: a systematic review. J Gastrointestin Liver Dis. 2010;19:409-14.

5. Della Libera E, Rohr MRS, Moraes M, Siqueira ES, Ferrari Jr AP. Eradication of Helicobacter pylori infection in patients with duodenal ulcer and non-ulcer dyspepsia and analysis of one-year reinfection rates. Braz J Med Biol Res. 2001;34:753-7.

6. Eisig, JN, Zaterka S, Silva FM, Malfertheiner P, Mattar R, Rodriguez TN, et al. Helicobacter pylori recurrence in patients with duodenal ulcer: clinical, endoscopic, histologic, and genotypic aspects. A 10 - year Brazilian series. Helicobacter. 2006;11:431-5.

7. Fikry AA, Kassem AA, Shahin D, Shabana HAS, Mostafa S. Helicobacter pylori infection in patients with chronic calcular cholecystitis a cross-sectional study. Journal of Surgery. 2014;2:58-62.

8. Fonseca FM, Etchebehere RM, Oliveira AG. Helicobacter pylori infection in patients undergoing upper endoscopy at University Hospital in Uberaba, Minas Gerais, Brazil. JMPHC. 2013:4:33-5.

9. Gisbert JP, Calvet X, Cosme A, Almela P, Feu F, Bory F, et al. Long-term follow-up of 1,000 patients cured of Helicobacter pylori infection following an episode of peptic ulcer bleeding. Am J Gastroenterol. 2012;107:1197-204.

10. Hagymási K, Tulassay Z. Helicobacter pylori infection: new pathogenetic and clinical aspects. World J Gastroenterol. 2014;20:6386-99.

11. Howden CW. Management of patients with Helicobacter pylori infection. Gastroenterol Hepatol. 2014;10(7 Suppl 3):13-6.

12. Ierardi E, Goni E, Losurdo G. Di Mario F. Helicobacter pylori and nonmalignant diseases. Helicobacter. 2014;19:27-31
13. Kidd M, Modlin IM. Century of Helicobacter pylori. Digestion. 1998;59:1-15

14. Kim SY, Hyun JJ, Jung SW, Koo JS, Yim HJ, Lee SW. Helicobacter pylori recurrence after first- and second-line eradication therapy in Korea: the problem of recrudescence or reinfection. Helicobacter. 2014;19:202-6.

15. Linz B, Balloux F, Moodley Y, Manica A, Liu H, Roumagnac P, et al. An African origin for the intimate association between humans and Helicobacter pylori. Nature. 2007:445(7130):915-8.

16. Matsuhisa T, Tsukui T. The first-line eradication rate for Helicobacter pylori infection in functional dyspepsia patients. J Gastroenterol Hepatol Res. 2014;3:1156-61.

17. Oliveira JG, Ferreira CHT, Camerin ACS, Rota CA, Meurer L, Silveira TR. Prevalence of infection with cagA-positive Helicobacter pylori strains among children and adolescents in southern Brazil. Arquivos de Gastroenterologia. 2014;51:180-5.

18. Papastergiou V, Georgopoulos SD, Karatapanis S. Treatment of Helicobacter pylori infection: past, present and future. World J Gastrointest Pathophysiol. 2014:5:392-9.

19. Rauws EAJ, Tytgat GNJ. Cure of duodenal ulcer associated with eradication of Helicobacter pylori. The Lancet. 1990;335:1233-5.

20. Reis Júnior JDD, Fernandes AB, Santos FS, Silva JHG, Loiola RP, Silva JG, et al. Soroprevalência da infecção por Helicobacter pylori em uma amostra rural do Estado do Amazonas, Brasil. Revista Pan-Amazônica de Saúde. 2012;3:33-6.

21. Silva FM, Navarro-Rodriguez T, Barbuti RC, Mattar R, Hashimoto CL, Eisig $\mathrm{JN}$. Helicobacter pylori reinfection in Brazilian patients with peptic ulcer disease: a 5-year follow-up. Helicobacter. 2010;15:46-52.

22. Smith SM, O'Morain C, McNamara D. Antimicrobial susceptibility testing for Helicobacter pylori in times of increasing antibiotic resistance. World J Gastroenterol. 2014;20:9912-21.

23. Toneto MG, Oliveira FJM, Lopes MHI. History of peptic ulcer: from etiology to treatment. Scientia Medica. 2011;21:23-30.

24. Vakil NB. Antibiotic resistance in patients with Helicobacter pylori infection. Gastroenterol Hepatol. 2014; 10(7 Suppl 3):9-13.

25. Yazbek PB, Trindade AB, Chin CM, Santos JL. Challenges to the treatment and new perspectives for the eradication of Helicobacter pylori. Dig Dis Sci. 2015;60:2901-12 